This item was submitted to Loughborough's Research Repository by the author.

Items in Figshare are protected by copyright, with all rights reserved, unless otherwise indicated.

\title{
Submarine gullies and an axial channel in glacier-influenced Courtauld Fjord, East Greenland
}

PLEASE CITE THE PUBLISHED VERSION

http://dx.doi.org/10.1144/M46.22

PUBLISHER

(C) Geological Society of London

VERSION

AM (Accepted Manuscript)

\section{PUBLISHER STATEMENT}

This work is made available according to the conditions of the Creative Commons Attribution-NonCommercialNoDerivatives 4.0 International (CC BY-NC-ND 4.0) licence. Full details of this licence are available at: https://creativecommons.org/licenses/by-nc-nd/4.0/

\section{LICENCE}

CC BY-NC-ND 4.0

\section{REPOSITORY RECORD}

Evans, Jeff, and Julian A. Dowdeswell. 2019. "Submarine Gullies and an Axial Channel in Glacier-influenced Courtauld Fjord, East Greenland”. figshare. https://hdl.handle.net/2134/16914. 


\title{
Submarine gullies and an axial channel in glacier-influenced Courtauld Fjord, East
}

\section{Greenland}

\author{
J. EVANS ${ }^{1} *$ \& J. A. DOWDESWELL ${ }^{2}$ \\ ${ }^{1}$ Department of Geography, Loughborough University, Loughborough LE11 3TU, UK \\ ${ }^{2}$ Scott Polar Research Institute, University of Cambridge, Cambridge CB2 1ER, UK
}

*Corresponding author (e-mail: j.evans2@lboro.ac.uk)

\begin{abstract}
Submarine gullies have been observed widely in swath-bathymetric imagery of the shelf edge and upper slope on high-latitude margins (e.g. Noormets et al. 2009; Gales et al. 2013), but less frequently in glacier-influenced fjord settings. Gullies vary in distribution, morphology and dimensions depending on formation mechanisms; these include submarine mass wasting, subglacially or proglacially derived turbid underflows and dense bottom-water currents linked to brine rejection during sea-ice formation (e.g. Noormets et al. 2009). Since recession of the Greenland Ice Sheet through the Kangerlugssuaq Fjord system, at $68^{\circ} \mathrm{N}$ in East Greenland, after the Last Glacial Maximum (Dowdeswell et al. 2010), significant seafloor erosion on the flanks of the inner tributary fjords has taken place to produce a series of submarine gullies and an axial channel (Fig. 1a-e).
\end{abstract}

\section{Description}

Well-defined linear and curvilinear landforms comprising steeply-bounded depressions, incised into the seafloor and separated by higher interfluve areas, are present perpendicular to bathymetric contours on the sloping flanks of the outer basin and outer sill of Courtauld Fjord, an inner tributary of Kangerlugssuaq Fjord, East Greenland (Fig. 1a-e). On the western side of Courtauld Fjord, the depressions commence part-way down the basin flank in water depths $>330 \mathrm{~m}$, and extend down to a maximum depth of $590 \mathrm{~m}$ (Fig. 1b). A few similar features are found on the upper fjord flanks, but they are subtle, smaller in scale, and isolated. The features generally comprise single linear forms and have V-shaped cross-sections and steep margins (Fig. 1b), and sometimes they coalesce in their lower reaches. The features are 450 to about $800 \mathrm{~m}$ in length, 50 to $200 \mathrm{~m}$ in width and 3 to $22 \mathrm{~m}$ deep. Axial slope gradients of the depressions are typically up to $15^{\circ}$.

In contrast, on the eastern side of the fjord landforms comprise linear to curvilinear depressions that coalesce in their middle to upper reaches to form a second-order network (Fig. 1c). The landforms initiate in water depths at or below $250 \mathrm{~m}$, and extend to 620 $\mathrm{m}$. They are larger than those on the western fjord flank (Fig. 1b, c), at about 750 to $2500 \mathrm{~m}$ long, 90 to $290 \mathrm{~m}$ in width and 3 to $42 \mathrm{~m}$ in depth (Fig. 1d). Axial slope gradients are up to $12^{\circ}$. Some gullies have fairly uniform widths along their entire length, with an elongated head, whilst others widen towards the head.

The mouths of the depressions open directly into a linear, $300 \mathrm{~m}$-wide channel-like conduit along the axis of the southwestplunging outer basin, which deepens from a prominent sill at $410 \mathrm{~m}$ to the $>750 \mathrm{~m}$ deep adjacent basin floor with a slope gradient of $4.4^{\circ}$ (Fig. 1a, b). The axial conduit or channel is featureless and is dominated by a smooth floor and no obvious landforms. The channel opens out onto the wide outer basin of the inner fjord. Above the sill, streamlined subglacial landforms are present on the shallower fjord floor closer to Courtauld Glacier (Fig. 1a).

\section{Interpretation}

The deeply incised fjord-flank depressions are interpreted as submarine gullies formed by down-slope transfer of sediment where relatively high-energy, gravity-driven flows erode the substrate. The bottom flows responsible for the gullies are likely to be generated by: (1) local retrogressive slope failures that caused the gullies to progressively cut vertically downward and headward, leading to the widening observed at the heads of some gullies (Fig. 1c); however, amphitheatre- or cauliflower-shaped gully heads, recognised on the Antarctic continental slope as signatures of this process (Noormets et al., 2009), are not observed; and/or (2) slope processes active above the gullied areas on the upper fjord flanks and outer sill slope. These processes include failure of subaerial-, glacimarine, or subglacial/ice-marginal derived sediment that translate to turbid sediment-gravity flows lower down the fjord sides.

East Greenland fjords have been characterised by rapid delivery and accumulation of glacigenic sediments both recently and during the Holocene and Late-Glacial, promoting significant sediment build-up, instability and down-slope sediment movement (e.g. Syvitski et al. 1996; Evans et al. 2002). Downslope underflows (Syvitski 1989) could also be derived from dense sediment-laden meltwater following discharge from tidewater glaciers and proglacial streams draining into Courtauld Fjord (Fig. 1a). Both mechanisms could have been more prevalent during periods when land-terminating glaciers, present on the eastern side of the fjord today (Fig. 1a), reached the coastline, and the tidewater Courtauld Glacier last advanced to the outer fjord sill during Little Ice Age (as demonstrated by the lateral moraine on the western subaerial fjord wall; Fig. 1a). Meltwater-derived flows are less likely to have contributed to formation of the western fjord gullies due to the absence of glaciers west of the fjord today and the limited size of proglacial river catchments (Fig. 1a).

The difference in submarine gully dimensions between the western and eastern fjord margins probably reflects contrasts in fjord slope-gradient and a higher rate and volume of sediment delivery onto the upper eastern flanks due to the presence of glaciers (Fig. 1a). The timing and duration of gully activity is uncertain; it is not known whether the gullies are active today or inactive, relict features dating to glacier advance during the Little Ice Age or much earlier during the last deglaciation of the inner fjord.

An absence of gully-mouth sediment lobes at the base of Courtauld Fjord indicates that the basin axis acts as a conduit or channel that enabled sediment-gravity flows exiting the gullies to continue to the deep basin-floor in outer Courtauld Fjord and the adjacent Kangerlugssuaq Fjord. The submarine gullies, coupled to the basin-axis conduit, form a channelised distributive system that provides 


\section{J. EVANS \& J.A. DOWDESWELL}

a pathway for sediment transfer down-slope from the upper fjord flanks to a deeper-water basin where greater accommodation space exists in a lower-energy environment (Fig. 1a).

\section{References}

DOWDESWELL, J. A., EVANS, J. \& Ó COFAIGH, C. 2010. Submarine landforms and shallow acoustic stratigraphy of a 400 km-long fjord-shelfslope transect, Kangerlussuaq margin, East Greenland. Quaternary Science Reviews, 29, 3359-3369.

EVANS, J., DOWDESWELL, J. A., et al. 2002. Late Quaternary sedimentation in Kejser Franz Joseph Fjord and the continental margin of East Greenland. In Dowdeswell, J.A. \& Ó Cofaigh, C. eds. Glacier-influenced sedimentation on high-latitude continental margins. Geological Society, London, Special Publication, 203, 149-179.

GALES, J. A., LARTER, R. D., MITCHELL, N. C. \& DOWDESWELL, J. A. 2013. Geomorphic signature of Antarctic submarine gullies: implications for continental slope processes. Marine Geology, 337, 112-124.

NOORMETS, R., DOWDESWELL, J. A., LARTER, R. D., Ó COFAIGH, C. \& EVANS, J. 2009. Morphology of the upper continental slope in the Bellingshausen and Amundsen Seas - implications for sedimentary processes at the shelf edge of West Antarctica. Marine Geology, 258, 100 114.

SYVITSKI, J. P. M. 1989. On the deposition of sediment within glacier-influenced fjords: oceanographic controls. Marine Geology, 85, $301-329$.

SYVITSKI, J. P. M., ANDREWS, J. T. \& DOWDESWELL, J. A. 1996. Sediment deposition in an iceberg-dominated glacimarine environment, East Greenland: basin fill implications. Global and Planetary Change, 12, 251-270.

Fig.1. Multibeam bathymetry and cross-profiles of submarine gullies in Courtauld Fjord, an inner tributary of Kangerlugssuaq Fjord, East Greenland. (a) Image showing submarine gullies in outer Courtauld Fjord and subglacial beforms in the inner fjord. A prominent sill separates the gullied outer fjord from the shallower inner fjord. Courtauld Glacier drains into the head of the fjord and several land- or tidewater-terminating glaciers are also present along the eastern flank of the fjord. Dashed white line and white arrows mark the lateral moraine on the western subaerial fjord wall produced when Courtauld Glacier last advanced to the outer fjord sill during the Little Ice Age. Acquisition system Kongsberg EM120. Frequency 12 kHz. Grid-cell size $25 \mathrm{~m}$. (b) Greyscale image representing an enlarged sub-area of (a), showing submarine gullies on the western fjord flank and outer fjord sill. (c) Greyscale swath image representing a sub-area of (a) showing the submarine gullies on the eastern fjord flank and outer sill slope. (d) $3.5 \mathrm{kHz}$ sub-bottom profile across the submarine gullies ( $\mathrm{x}-\mathrm{x}$ ’ in Fig. 1a). Note the acoustically prolonged seafloor reflector indicating sedimentary substrate. The acquisition system is Kongsberg TOPAS PS 018 with a secondary beam frequency of 0.5-6 kHz. (e) Location map showing the study area (red box) (map from IBCAO Version 3.0). 

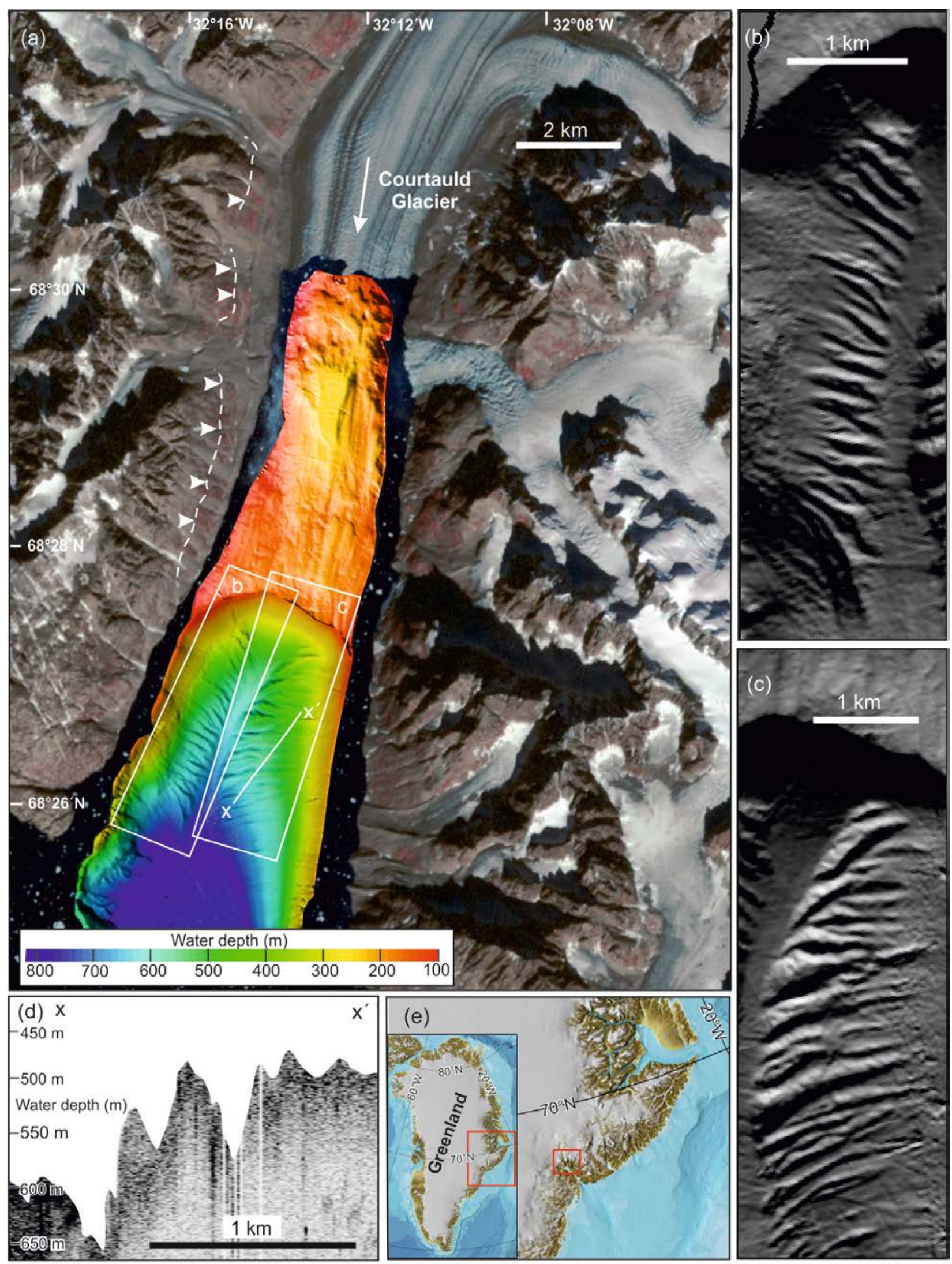

Figure 1 